\title{
NANOEMULSION FORMATION BY LOW-ENERGY METHODS: A REVIEW
}

\author{
Yu.V.Sokolov \\ “AT Biopharm” JSC, Kharkiv, Ukraine \\ Key words: nanoemulsion; low-energy emulsification; self-emulsification; phase inversion \\ temperature (PIT); phase inversion composition (PIC)
}

\begin{abstract}
The interest in nanoemulsions has experienced a continuous increase in the last years as evidenced by the numerous publications and comprehensive reviews on the subject. This enormous interest is triggered by the wide range of applications, namely in the pharmaceutical, cosmetic, food, chemical industries. Nanoemulsions (submicrometer-size droplets) have advantages over conventional emulsions (micrometer-size droplets) due to their small droplet size; it stipulates their stability against sedimentation or creaming and a transparent or translucent optical aspect (similar to that of microemulsions). Nanoemulsions are commonly prepared by high-energy methods using mechanical devices, which can produce intense disruptive forces, for example, high pressure homogenizers and ultrasound generators. Nanoemulsion formation by these methods is quite straightforward as the higher the energy input is, the smaller is the droplet size. However, the level of energy required to obtain nanometer-scaled droplets is very high, and therefore, cost-inefficient, especially considering that only a small amount of the energy produced is used for emulsification. In contrast, low-energy emulsification methods using the internal chemical energy of the system are often more energy efficient as only simple stirring is needed, and generally allow producing a smaller droplet size than high-energy methods. It has been also claimed that high-energy methods allow preparing nanoemulsions at higher oil-to-surfactant ratios than low-energy methods. The results obtained confirm that both PIT and PIC have the same mechanisms. However, there are still issues to be solved. One of them concerns the possibility to obtain nanoemulsions with the minimum droplet size and low polydispersity by the PIC method. It is likely that the kinetics of the emulsification process plays an important role in this emulsification method, which has not been taken sufficiently into account. Therefore, more research effort needs to be done on this subject. A more comprehensive knowledge on the mechanisms involved in nanoemulsion formation by low-energy methods will allow their optimization and consequently will extend the fields of their application.
\end{abstract}

The interest in nanoemulsions has experienced a continuous increase in the last years as evidenced by the numerous publications and comprehensive reviews [12, $14,19,22,31]$ on the subject. This enormous interest is triggered by the wide range of applications, namely in the pharmaceutical $[2,3,6,9,10,13,19,22,28,36$, $37]$, cosmetic $[1,7,34,40]$, food $[15,26,27,29]$, chemical $[5,17,23,25]$, etc., industries. Nanoemulsions (submicrometer-size droplets) have advantages over conventional emulsions (micrometer-size droplets) due to their small droplet size; it stipulates their stability against sedimentation or creaming and a transparent or translucent optical aspect (similar to that of microemulsions). However, nanoemulsions, in contrast to microemulsions, which are thermodynamically stable, are nonequilibrium systems, which may undergo flocculation, coalescence and/or Ostwald ripening. Nevertheless, with an appropriate selection of the system components, composition and preparation method, nanoemulsions with a high kinetic stability can be obtained. It is generally accepted $[21,30,33]$ that the nanoemulsion main breakdown process is Ostwald ripening (diffusion of molecules of the disperse phase from small to big droplets). However, recent reports have shown flocculation to be a possible breakdown mechanism for nanoemulsions formulated with mixed nonionic-ionic surfactants $[38,39]$.
Nanoemulsions are commonly prepared by highenergy methods using mechanical devices, which can produce intense disruptive forces, for example, highshear stirrers, high pressure homogenizers and ultrasound generators. Nanoemulsion formation by these methods is quite straightforward as the higher the energy input is, the smaller is the droplet size. However, the level of energy required to obtain nanometer-scaled droplets is very high, and therefore, cost-inefficient, especially considering that only a small amount (about $0.1 \%$ ) of the energy produced is used for emulsification [32]. In contrast, low-energy emulsification methods using the internal chemical energy of the system are often more energy efficient as only simple stirring is needed, and generally allow producing a smaller droplet size than high-energy methods [36]. Nevertheless, depending on the system and composition variables, similar droplet sizes can be obtained by both types of methods [41]. It has been also claimed that high-energy methods allow preparing nanoemulsions at higher oil-to-surfactant ratios than low-energy methods [41]. However, nanoemulsions with high oil-to-surfactant ratios prepared by low-energy methods have also been reported [9].

\section{Low-energy emulsification methods}

Low-energy approaches rely on the spontaneous formation of tiny oil droplets within oil-water-emulsifier 
mixtures when either their composition or the environmental conditions are altered. A number of different nanoemulsion preparation methods are based on this principle, including spontaneous emulsification (SE), phase inversion temperature (PIT), phase inversion composition (PIC), and emulsion inversion point (EIP) methods [4, 8, 16, 24].

Spontaneous emulsification. In this group of methods an emulsion or nanoemulsion is spontaneously formed when two liquids (usually an organic phase and an aqueous phase) are mixed together at a particular temperature [24]. For example, an organic phase consisting of a non-polar oil and a hydrophilic surfactant and/or a watermiscible organic solvent may be slowly added to water. Alternatively, water may be added to an organic phase containing a non-polar oil, a water-miscible organic solvent and a surfactant [31]. The water-miscible organic solvent is typically ethanol or acetone, but it may be replaced with a water-miscible surfactant instead.

To obtain very small droplets, as is required in nanoemulsions, it is usually necessary to use a high ratio of the water-miscible component-to-oil in the organic phase prior to mixing. The spontaneous emulsification method has found a widespread utilization within the pharmaceutical industry, where it is used to form drug delivery systems to encapsulate and deliver lipophilic drugs. Systems prepared using this approach are usually referred to as either Self-Emulsifying Drug Delivery Systems (SEDDS) or Self-Nanoemulsifying Drug Delivery Systems (SNEDDS) depending on the droplet size produced. A great deal of research has gone into optimizing the formulation of SEDDS and SNEDDS in terms of identifying the most appropriate preparation method and compositions. The main drawback when using this approach in the food industry is that high concentrations of synthetic surfactants are normally needed, which may be undesirable due to regulatory, cost or sensory reasons. Nevertheless, there are certainly some applications where this approach may be useful, e.g., incorporating small amounts of bioactive lipophilic components into beverages.

Phase inversion methods. The phase inversion temperature (PIT) method relies on changes in the optimum curvature (molecular geometry) or solubility of non-ionic surfactants with changing temperature $[14,22]$. For example, nanoemulsions can be spontaneously formed using the PIT method by varying the temperature-time profile of certain mixtures of oil, water and non-ionic surfactant. This type of phase inversion usually involves the controlled transformation of an emulsion from one type to another (e.g., W/O to $\mathrm{O} / \mathrm{W}$ or vice versa) through an intermediate bicontinuous phase. The driving force for this type of phase inversion is changes in the physicochemical properties of the surfactant with temperature. The molecular geometry of a surfactant molecule can be described by a packing parameter, $p$ [16].

At low temperatures, the head group of a non-ionic surfactant is highly hydrated, and so it tends to be more soluble in water. As the temperature increases, the head group becomes progressively dehydrated and the solubility of the surfactant in water decreases. At a particular temperature (PIT), the solubility of the surfactant in the oil and water phases is approximately equal. At higher temperatures, the surfactant becomes more soluble in the oil phase than in the water phase. A nanoemulsion can be formed spontaneously by rapid cooling of an emulsion from a temperature at or slightly above the PIT to a temperature well below the PIT.

The phase inversion composition or PIC method is somewhat similar to the PIT method, but the optimum curvature of the surfactant is changed by altering the composition of the system rather than the temperature. For example, an $\mathrm{O} / \mathrm{W}$ emulsion stabilized by an ionic surfactant can be subjected to phase invertion to a $\mathrm{W} / \mathrm{O}$ emulsion by adding a salt. In this case, the packing parameter is adjusted from $p<1$ to $p>1$ due to the ability of the salt ions to screen the electrical charge on the surfactant head groups [20]. Alternatively, a W/O emulsion containing a high salt concentration can be converted into an $\mathrm{O} / \mathrm{W}$ emulsion by diluting it in water, i.e. reducing the ionic strength below some critical level.

Emulsion inversion point. In the emulsion inversion point (EIP) methods the change from one type of an emulsion to another (e.g., W/O to O/W or vice versa) is through a catastrophic phase inversion (CPI), rather than a transitional phase inversion (TPI) as with the PIC or PIT methods $[11,35]$. In this case, a W/O emulsion with a high oil-to-water ratio is formed using a particular surfactant, and then increasing amounts of water are added to the system with continuous stirring. Above a critical water content, the water droplet concentration is so high that they are packed very tightly together, and the emulsion reaches a phase inversion point where it changes from a W/O to an $\mathrm{O} / \mathrm{W}$ system. The size of the droplets formed depends on the process variables, such as the stirring speed and the rate of water addition [35]. The emulsifiers used in catastrophic phase inversion are usually limited to small molecule surfactants that are able to stabilize both $\mathrm{W} / \mathrm{O}$ emulsions (at least over the short term) and $\mathrm{O} / \mathrm{W}$ emulsions (for a long term). Recently, it has been shown that the emulsion inversion point (CPI) method can be used to produce nanoemulsions $(\mathrm{r}<100 \mathrm{~nm})$ from food-grade ingredients [26].

\section{CONCLUSIONS}

Nanoemulsions cause constant and growing interest as due to their characteristic properties (small size, large surface area and transparent optical properties) they are advantageous over other colloidal systems for a wide range of applications. It is worth noting the interest to nanoemulsions for application in pharmacy, cosmetics, agrochemical, food, chemical industries, etc. Low-energy emulsification methods have focussed considerable research interest in the last years as small droplet sizes and narrow size distributions can be obtained using simple equipment. The review on formation of nanoemulsions by self-emulsification and phase inversion (PIT and PIC) methods confirms the progress in studying the factors leading to nanoemulsions with the minimum size and low polydispersity. The results obtained confirm that both PIT and PIC have the same mechanisms. However, there are still issues to be solved. One of them concerns 
the possibility to obtain nanoemulsions with a minimum droplet size and low polydispersity by the PIC method. It is likely that the kinetics of the emulsification process plays an important role in this emulsification method, which has not been taken sufficiently into account. There- fore, more research effort needs to be done on this subject. A more comprehensive knowledge on the mechanisms involved in nanoemulsion formation by low-energy methods will allow their optimization and consequently will extend the fields of their application.

\section{REFERENCES}

1. Al-Edresi S., Baie S. // Int. J. Pharm. - 2009. - Vol. 373. - P. 174-178.

2. Anton N., Benoit J.-P., Saulnier P. // J. Control. Release. - 2008. - Vol. 128. - P. 185-199.

3. Anton N., Mojzisova H., Porcher E. et al. // Int. J. Pharm. - 2010. - Vol. 398. - P. 204-209.

4. Anton N., Vandamme T.F. // Int. J. Pharm. - 2009. - Vol. 377. - P. 142-147.

5. Aubry J., Ganachaud F., Addad J.-P.C., Cabane B. //Langmuir. - 2009. - Vol. 25. - P. 1970-1979.

6. Beck-Broichsitter M., Rytting E., Lebhardt T. et al. // Eur. J. Pharm. Sci. - 2010. - Vol. 41. - P. $244-253$.

7. Bernardi D.S., Pereira T.A., Maciel N.R. et al. // J. Nanobiotechnol. - 2011. - Vol. 9, №44.

8. Bilbao-Sáinz C., Avena-Bustillos R.J., Wood D.F. et al. // J. Agric. Food. Chem. - 2010. - Vol. 8. - P. 11932-11938.

9. Calderó G., García-Celma M.J., Solans C. // J. Colloid. Interface Sci. - 2011. - Vol. 353. - P. 406-411.

10. Date A.A., Desai N., Dixit R., Nagarseker M. // Nanomedicine. - 2010. - Vol. 5. - P. 1595-1616.

11. Fernandez P., Andre V., Rieger J., Kuhnle A. // Colloids Surf., A. - 2004. - Vol. 251. - P. 53-58.

12. Fryd M.M., Mason T.G. // Annu. Rev. Phys. Chem. - 2012. - Vol. 63. - P. 493-518.

13. Ghai D., Sinha V.R. // Nanomedicine-Nanotechnol. - 2012. - Vol. 8. - P. 618-626.

14. Gutiérrez J.M., González C., Maestro A. et al. //Curr. Opin. in Colloid. Interface Sci. - 2008. - Vol. 13. - P. $245-251$.

15. Henry J.V.L., Fryer P.J., Frith W.J., Norton I.T. // Food Hydrocolloids. - 2010. - Vol. 24. - P. 66-71.

16. Israelachvili J. Intermolecular and Surface Forces. 2-nd ed. -Academic Press, London, 1992.

17. Lucas P., Vaysse M., Aubry J. et al. // Soft Matter. - 2011. - Vol. 7. - P. 5528-5531.

18. Maali A., Hamed Mosavian M.T. // J. Dispersion Sci. Technol. - 2012. - Vol. 1. - P. 1-24.

19. Machado A.H.E., Lundberg D., Ribeiro A.J. et al. // Langmuir. - 2012. - Vol. 28. - P. 4131-4141.

20. Maestro A., Sole I., Gonzalez C. et al. // Colloid Interface Sci. - 2008. - Vol. 327. - P. 433-439.

21. McClements D.J. // Soft Matter. - 2011. - Vol. 7. - P. 2297-2316.

22. Morral-Ruíz G., Solans C., García M.L., García-Celma M.J. //Langmuir. - 2012. - Vol. 28. - P. 6256-6264.

23. Muñoz-Espí R., Weiss C.K., Landfester K. // Curr. Opin. Colloid. Interface Sci. - 2012. - Vol. 17. - P. $212-224$.

24. Pouton C.W., Porter C.J.H. Formulation of Lipid-Based Delivery Systems for Oral Administration: Materials, Methods and Strategies. - San Antonio, TX, 2006.

25. Ragupathy L., Ziener U., Robert G., Landfester K. // Colloid. Polym. Sci. - 2011. - Vol. 289. - P. 229-235.

26. Rao J., McClements D.J. // J. Agric. Food. Chem. - 2010. - Vol. 58. - P. 7059-7066.

27. Rao J., McClements D.J. // J. Agric. Food. Chem. - 2011. - Vol. 59. - P. 5026-5035.

28. Shakeel F., Ramadan W., Faisal M.S. et al. // Curr. Nanosci. - 2010. - Vol. 6. - P. 184-198.

29. Silva H.D., Cerqueira M.A., Vicente A.A. // Food. Bioprocess. Technol. - 2012. - Vol. 5. - P. 854-867.

30. Solans C., Solè I., Fernández-Arteaga A. et al. Nano-emulsion formation by low-energy methods and functional properties. In: Hidalgo-Álvarez Roque, editor. - Structure and functional properties of colloidal systems. Surfactant science series Taylor and Francis Group, 2009. - P. 457-482.

31. Sonneville-Aubrun O., Babayan D., Bordeaux D. et al. // Phys. Chem. Chem. Phys. - 2009. - Vol. 11. - P. 101-110.

32. Tadros Th.F., Izquierdo P., Esquena J., Solans C. // Adv. Colloid. and Interface. - 2004. - Vol. 108-109. P. 303-318.

33. Taylor P. // Adv. Colloid. and Interface. - 1998. - Vol. 75. - P. 107-163.

34. Teo B.S.X., Basri M., Zakaria M.R.S. et al. // J. Nanobiotechnol. - 2010. - Vol. 8, №4.

35. Thakur R.K., Villette C., Aubry J.M., Delaplace G. // Colloids Surf., A. - 2008. - Vol. 315. - P. $285-293$.

36. Vandamme T.F., Anton N. // Int. J. Nanomedicine. - 2010. - Vol. 5. - P. 867-873.

37. Wang L., Dong J., Chen J. et al. // J. Colloid. Interface Sci. - 2009. - Vol. 330. - P. 443-448.

38. Wang L., Mutch K.J., Eastoe J. et al. // Langmuir. - 2008. - Vol. 24. - P. 6092-6099.

39. Wang L., Tabor R., Eastoe J. et al. // Phys. Chem. Chem. Phys. - 2009. - Vol. 11. - P. 9772-9778. 
40. Wu X., Guy R.H. // J. Drug. Deliv. Sci. Technol. - 2009. - Vol. 19. - P. 371-384.

41. Yang Y., Marshall-Breton C., Leser M.E. et al. // Food Hydrocolloids. - 2012. - Vol. 29. - P. 398-406.

\author{
ОТРИМАННЯ НАНОЕМУЛЬСІЙ ЗА ДОПОМОГОЮ НИЗЬКОЕНЕРГЕТИЧНИХ МЕТОДІВ: \\ ОГляд \\ Ю.В.Соколов \\ Ключові слова: наноемульсія; низькоенергетичне емульгування; самоемульгування; \\ температура фразової інверсії; композиція фразової інверсії
}

Інтерес до наноемульсій в останні роки постійно зростає, що підтверджується численними публікаціями і оглядами за цією темою. Такий зростаючий інтерес викликаний широким діапазоном застосування у фрармацевтичній, косметичній, харчовій, хімічній промисловостях. Наноемульсії (частинки субмікронного розміру) мають перевагу перед звичайними емульсіями (частинками мікронного розміру) завдяки меншому розміру, що зумовлює їх стійкість до осадження та кремажу і оптичну прозорість. Наноемульсії зазвичай виробляють за допомогою високоенергетичних методів з використанням механічних приладів, здатних виробляти інтенсивні руйнуючі сили, наприклад, гомогенізатори високого тиску та ультразвукові генератори. Розмір частинок наноемульсій, що утворюються за допомогою таких методів, тим менший, чим більше застосовується енергії. Рівень енергії, необхідної для утворення наночастинок, є дуже великим, внаслідок чого процес є економічно неефективним, особливо якщо врахувати те, що лише невелика частина цієї енергії витрачається на емульгування. Низькоенергетичні методи, навпаки, використовують внутрішню хімічну енергію системи, тому вони, як правило, більш енергетично ефективні, $m$. я. достатньо простого перемішування, що в більшості випадків дозволяє отримати частинки меншого розміру, ніж 3 використанням високоенергетичних методів. Отримані результати підтверджують, що в основі як ТФІ, так і КФІ лежать ті самі механізми. Однак залишаються ще невирішені питання. Одне з них відноситься до можливості отримання НЕ з мінімальним розміром частинок та низькою полідисперсністю за допомогою методу КФІ. Скоріше за все кінетика процесу емульгування відіграє важливу роль у цьому методі, на який не звертали достатньо уваги. Отже, необхідно більше досліджень за цією темою. Більш глибоке знання механізмів фрормування НЕ за допомогою НЕМ дозволить проводити їх оптимізацію та послідовно розширювати області їх застосування.

\title{
ПОЛУЧЕНИЕ НАНОЭМУЛЬСИЙ С ПОМОЩЬЮ НИЗКОЭНЕРГЕТИЧЕСКИХ МЕТОДОВ: ОБЗОР \\ Ю.В.Соколов \\ Ключевые слова: наноэмульсия; низкоэнергетическое эмульгирование;
} самоэмульгирование; температура фразовой инверсии; композиция фразовой инверсии Интерес к наноэмульсиям в последние годы постоянно растет, что подтверждается многочисленными публикациями и обзорами по этой теме. Этот растущий интерес вызван широким диапазоном применения в фрармацевтической, косметической, пищевой, химической промышленностях. Наноэмульсии (частицы субмикронного размера) имеют преимущество перед обычными эмульсиями (частицами микронного размера) благодаря меньшему размеру, что обусловливает их устойчивость к осаждению и кремажу и оптическую прозрачность. Наноэмульсии, как правило, производятся с помощью высокоэнергетических методов с использованием механических устройств, способных производить интенсивные разрушающие силы, например, гомогенизаторы высокого давления и ультразвуковые генераторы. Размер образующихся частиц наноэмульсий с помощью этих методов тем меньще, чем больше прикладывается энергии. Уровень энергии, необходимой для образования наночастии, очень велик и вследствие этого неэкономичен, особенно если учесть, что лишь малая доля этой энергии расходуется на эмульгирование. Низкоэнергетические методы, наоборот, используют внутреннюю химическую энергию системы, зачастую более энергетически эффоктивны, т. к. достаточно простого перемешивания, чтобы в большинстве случаев получить частицы меньшего размера, чем с использованием высокоэнергетических методов. Полученные результаты подтверждают, что в основе и ТФИ, и КФИ лежат одни и те же механизмы. Однако остаются еще нерешенные вопросы. Один из них относится к возможности получения НЭ с минимальным размером частиц и низкой полидисперсностью с помощью метода КФИ. Скорее всего кинетика процесса эмульгирования играет важную роль в этом методе, который не принимался достаточно во внимание. Следовательно, необходимо больще исследований по этой теме. Более глубокое знание механизмов формирования НЭ с помощью НЭМ позволит проводить их оптимизацию и последовательно расширять области их применения. 